These respondents represented the 67 th percentile of all participants who provided details of their success. That is, participants who achieved these goals were more successful than two-thirds of all other participants. We selected the 67th percentile -- as opposed to, say, the 90th percentile or the 75 th percentile -based on natural breakpoints in the data. There was a clear cluster of data points in the top third.

But that's not the interesting part.

What's interesting is what these successful companies did differently from less successful organizations. Nemertes compiled these results into an loT maturity model that companies can use as their roadmap to success (see figure).

The maturity model comprises four levels: unprepared -- the organization lacks tools and processes to address the loT initiative; reactive -- the organization has platforms and processes to respond to but not proactively address the issue; proactive -- the organization has the tools and processes to proactively deliver on the issue as it is currently understood; and anticipatory -- the organization has the tools, processes and people to handle future requirements.

The third of organizations in the survey with successful loT deployments were likely to be at Level 2 or Level 3 loT maturity, and in a couple of areas -- namely executive sponsorship, budgeting and architecture -successful organizations far outshone organizations that were less successful.

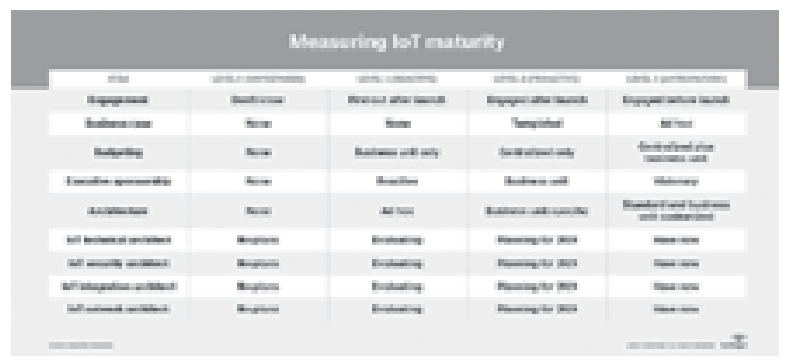

the initiative. This could be a business or technology leader, such as the head of innovation, CTO or head of operations.

In addition, key loT team members include the IoT architect, IOT security architect, IoT network architect and IoT integration architect. Most large organizations have different architects that encompass these responsibilities, though their job titles may not reflect it.

For instance, an loT cybersecurity architect may have the title of cybersecurity architect, but over a year or two, her job functions may morph from mostly security with some IoT to mostly loT security with some other cybersecurity. It all depends on whose responsibility the loT portion is.

Speaking of loT teams, the research interestingly found an IOT business strategist and an IoT analytics architect were often not included in planning processes. The loT business strategist and loT analytics architect likely don't show up as success characteristics because most organizations have someone who can handle business strategy or analytics, and the IoT element isn't as strong of a differentiator as it is with a security architect, for example.

In other words, business strategy architects and analytics architects are two roles that make IoT more similar to other business strategy or analytics issues and wouldn't require a specialized role or responsibility, per se.

The research also mentioned that successful organizations stand out because they have both a standardized loT architecture and customized versions for specific loT projects. They also budget for loT both centrally and by business unit.

To sum up: If you're looking to be successful in your IoT initiatives, you should take the following steps:

- Don't start an loT initiative until you have a committed, visionary leader at either the business unit level or the corporate level. If it's someone who's reluctant to do it at all or if you have no one, your chances of success are significantly diminished.

- Work to have your team engaged in the planning stages.

- Start with a general, overarching loT architecture and plan to customize it for specific projects.

- If possible, secure budgeting for loT projects at both the corporate and business unit level. If you can't do both, start with business unit-level funding and plan for both in upcoming fiscal years.

- Make sure your IoT team includes, at a minimum, an loT architect, an loT integration architect and an IoT security architect.

This was last published in April 2019 


\section{An loT Maturity Model and Tips for IoT Deployment Success}

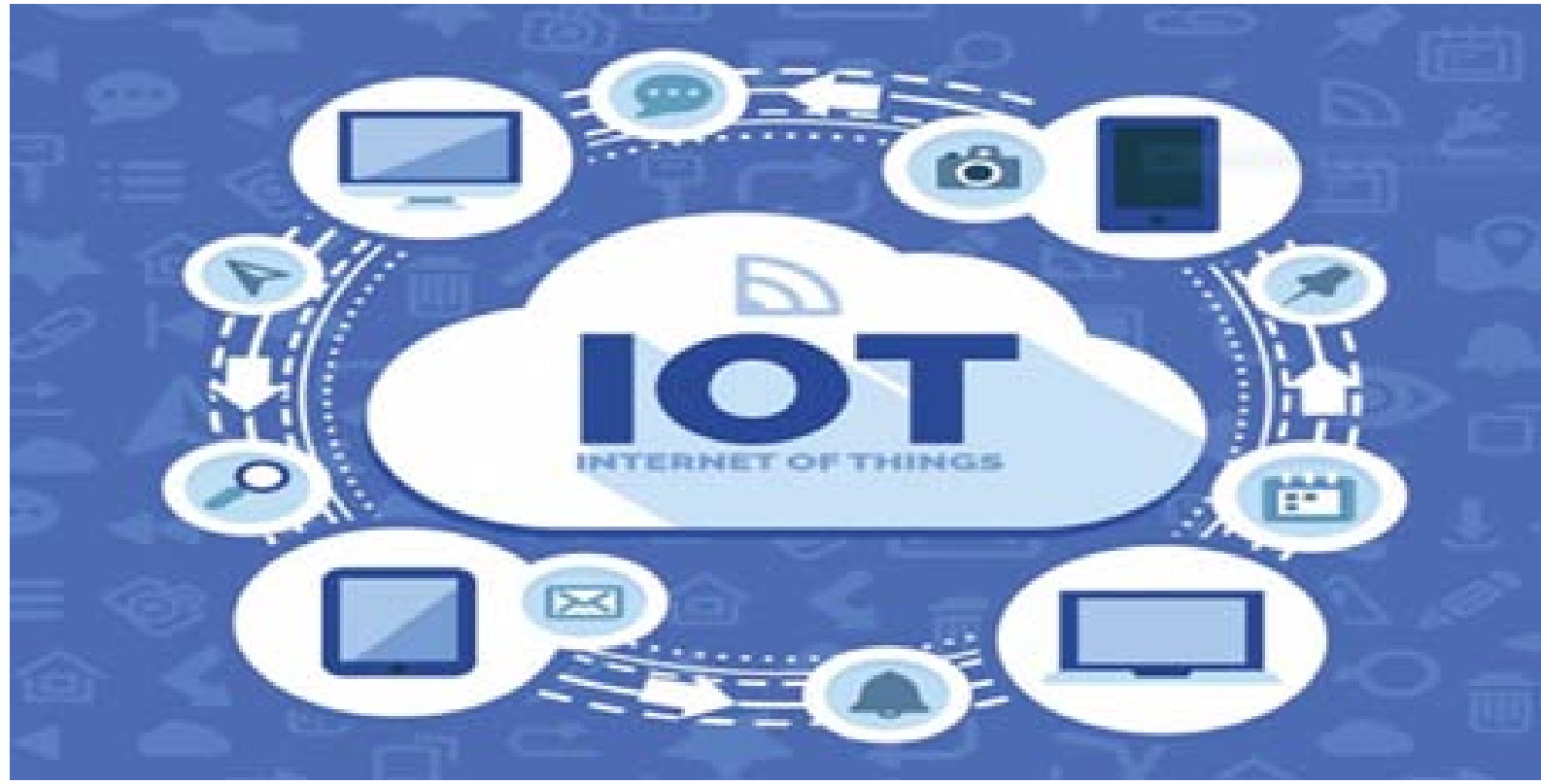

\section{Ready to tread an Internet of Things ( loT) path? Get help from those who have benefitted from loT before with this loT maturity model road- map with tips for success.}

What makes one loT initiative more successful than another? There are many answers to that question.

In its "IoT Research Study 2019," Nemertes took the following stance: Organizations deploy loT for one of three main reasons: They want to generate new revenue, either in the form of creating new business models, improving the revenue generated by existing lines of business or attracting new customers; they want to reduce the cost of operations; or they want to improve business processes to perform the same functions faster, better or at a lower cost.

In other words: IoT success means new dollars, saved dollars or improved processes.

The study looked at 403 organizations across 13 countries and a range of sizes and vertical industries.
It asked participants whether or not they had an IoT initiative that they considered successful. For those who said they did, Nemertes drilled into the specifics: What was the goal of the initiative? What was the design? How long did it take to deploy? How many loT devices did it include? And based on the success metric identified by the participant, what tangible success did it generate?

Nemertes Research The state of loT maturity

The research found that successful IoT initiatives, which accounted for about a third of respondents, generated at least $\$ 2.5$ million in new revenue, saved at least $\$ 1.2$ million in costs or improved business processes by $35.5 \%$-- depending, of course, on the goal of the participant. 